\title{
The Effect of Globalization and Modernisation on Selling Power Decrease of Toys Street-Seller in the City
}

\author{
Regina Angelica Kezia*; Mugijatna; Wakit Abdullah Rais \\ Prodi Kajian Budaya Pascasarjana Universitas Sebelas Maret, Indonesia \\ Email: reginaangelicakezia@gmail.com
}

http://dx.doi.org/10.18415/ijmmu.v5i4.268

\begin{abstract}
This research studies several toys street-seller in the city, whose data is obtained through electronic paper media. This research has a purpose to describe how globalization and modernisation contribute to the decrease of appeal towards toys, which are sold in the street. The method used in this research is qualitative method. The theory used is the theory of William Ogburn concerning the culture barrier and subject of modernisation. The result of this research shows that the main cause of decrease of appeal towards toys street-seller is due to dispersion of mobile games because of globalization and modernisation, besides the intricate regulations on toys standard which caused the high price tag on toys which are sold on the street, that resulted in the proliferation of mobile games.
\end{abstract}

Keywords: Modernisation; Globalization; Board Game; Toys Street-Seller;

\section{Introduction}

The wave of globalization and openness of information made everything easier. Globalization is defined as process of opening or entering the global interaction. The word 'global' itself stems from the word 'globe' which means 'the earth'. Globalization is also can be defined as a worldwide practice. Globalization is a term which connects to the increase of international and interpersonal communication in the whole world. The vast and populous world with various nationalities is viewed as a single worldwide nation or citizen. In globalization, there is no boundaries between countries. Drucker stated that the definition of globalization includes the whole process of global economy, instant proliferation of information, the fast acceleration of international trade, and money market.

There is nothing constant in the world except change itself. Change transforms every aspect. The phenomenon of change is often caused dilematic situation in the societal life between negative and positive perception towards the change. Negative perspective views change as something abnormal, which translates to crises, tortures, traumatic experience, therefore change is viewed as "future shocks". Positive perspective views change as inevitable, for change will cause development. Wilbert Moore (in Suparlan Al Hakim., 2015: 105) stipulates that social change as important change in social structure, which covers the pattern of behavior and social interaction, which includes norms, values, and cultural phenomenon. According to Fairchild, social change is modification of every aspect of social process, 
social patterns, and social forms, and interrelation pattern. Selo Sumardjan also argues that social change is an advance state of social institution.

The changes due to wave of globalization and advancement of technology do not only producing positive effects in the form of high effectivity and simplify works, but also caused negative effects, such as the change of individual personality in the form of laziness, self-preservation, and introvert behavior. This is caused by simplicity and easeness of access. Besides of that, the effect of the wave of globalization in the industry sector, in which machines replace manpower, is the growth of capitalization in every aspect of life, such as fully automated factories and industries. This caused unemployment, reduced or polluted land, and the main emphasis of life to work continually. Consumerization could also be caused by this condition.

The data used in this research is several pieces of news found in selected online circulation with the theme toy street-seller, for example from Tribunnews with the title Tahun ini Pedagang Mainan di Pasar Gembrong Tidak Untung on July 28th, 2014 and from Vemale.com with the title Mang Kodir, Penjual Mainan Keliling yang Bertahan di Era Gadget.

Just like toys street-seller who are often flocking in the front of elementary schools, waiting for children to buy their merchandise. Some of the toys sold are toy cars with the brand Tamiya, snakes and ladders, checkers, small-sized magnetic chess, and so forth. With the passing of time, the number of these toys seller is decreasing due to children prefer to play with their gadget and choose as many games as possible, which are available in the applications.

Previous research is conducted by Yeni Ristiana in her thesis, which was published by Universitas Negeri Yogyakarta in the year 2008, which delves into interaction patterns occurred in a socalled 'cyber village' in Patehan, Yogyakarta. My research is different with previous research, because this research studies the phenomenon in the city, and its correlation with the modernisation and globalization, which brought forth the virtual games.

This phenomenon is interesting to be studied to understand how the change in modern society which prefers gadget than playing with friends and purchasing merchandises sold by toys street-seller and what is the effect of the wave of globalization, which caused the inequality in the society. The objective of this research is to explain and describe how the phenomenon of globalization and advanced technology are able to transform the taste and ways of playing in the society, particularly for elementary school children in urban context, and to describe effects caused to the livelihood of toys street-seller, which is declining as time passed.

\section{Methodology}

This research belongs to cultural studies, because Chris Barker explains that on the whole, cultural studies has favoured qualitative methods with their focus on cultural meaning, so that the method used in this research is qualitative method.

Qualitative method uses qualitative analysis; rather than quantitative analysis, the data mainly contains words. According to Strauss and Corbin (1998: 24), qualitative research is a research not made possible by the gathering of statistical procedures or the other way of quantification (measurement). The qualitative method could be also described as interpretative research, which is essentially descriptive. Generally, qualitative research can be used to research societal life, history, behaviour, social, and others. Bogdan and Biklen, S (1992: 21-22) explain that qualitative research produces descriptive data in the 
form of observed speech or writing. The qualitative research strives to acquire an understanding of social reality from the participant's perspective.

Work in cultural studies has centred on three kinds of approach (Barker., 2000: 25), in which one of them is ethnography. Ethnography is an empirical and theoretical approach inherited from anthropology that seeks detailed holistic description and analysis of cultures based on intensive fieldwork. The objective is to produce what Geertz (1973) famously described as "thick descriptions" of the multiplicity of complex conceptual structures. Ethnography concentrates on the details of local life while connecting them to wider social processes.

Due to primary data used in this research are news obtained from an event occurred in the society, therefore this research used ethnography and textual study. The primary data are several pieces of news found in selected online circulation with the theme of toys street-seller, for example from Tribunnews with the title Tahun ini Pedagang Mainan di Pasar Gembrong Tidak Untung on July 28th, 2014 and from Vemale.com with the title Mang Kodir, Penjual Mainan Keliling yang Bertahan di Era Gadget. Meanwhile, the secondary data of this research are scientific works, information obtained in networks, books, and papers.

Modernisation as the indicator of social change is crucial for a society, particularly for an open society. Modernisation is viewed as necessary, because it relates to the effects occurred in a society, positive or negative. Modernisation is closely connected to globalization, in which the renewal is society is even quicker with the advancement of technology. Technology somehow will bring progressive effects to a society, e.g. modernisation made it easier for a society to absorb technology, and makes the transformation of society mindset even faster. Modern society is entering information era, in which Alfin Toffler with his book, The Third Wave, in Soemardjan (1993: 111) stipulated that mankind passed through three consecutive stage: 1. Agriculture stage 2. Industrial stage 3. Information stage..

Modern society experienced more growth in their life and now they are entering information era, in which every countries strive to connect every rural areas, education institutions, public institutions, governmental institutions, and so forth in a single network, therefore making interaction in every aspect of global communication as easy and quick as possible through the use of telematics. The development of information globalization supported by the advancement of technology has changed traditional aspects of a society, and makes it easier for the society to live their life. This is proved by the pioneer of information technology which gave way to sophisticated computer system, which is International Networking (Internet). Internet or International Networking is the result of relationship between information technology and communication, which fascinates many people in the world.

According to Soedjito (1991: 73), modern technology is a value-free factor, which means it can be used for pretty much anything and preserve the value of life, e.g. the eradication of cancer, but also to destroy, as for crime, so technology depends on the user to produce goodness or harm. Internet was introduced in Indonesia in the middle of 1990s and since then has grown into the state of basic necessity for the modern society which depends on technology and information.

This research used Cultural Lag theory, then known as the Cultural Barrier introduced by William F. Ogburn. The term "Cultural Barrier" refers to the idea that a culture needs time to cover its lag from technological advancement, and it caused problems and social conflicts. Cultural barrier can also be applied to other than this idea, but it also has theories and elucidations. This concept operates by identifying and describing social problems, and also useful for detecting social problems in the future. As described by James W. Woodward (1934), when material condition changes, the material culture will also change, but when the change in this adaptive culture is not synchronized correctly with the change of material culture, therefore it can be described as cultural lag. This term is introduced for the first time by 
sociologist William F. Ogburn (1966). His theory of cultural barriers says that there will be a period of adjustment that occurs when the non-material culture seeks to conform to the material conditions (1957).

According to Ogburn, cultural barriers are a common social phenomenon because of the rapidly changing tendencies of material culture, while non-material cultures tend to resist change and are difficult to change in a short period of time. Because of the opposite nature of these two aspects of culture, adaptation to new technology becomes quite difficult. This distinction between material and non-material culture is also one of Ogburn's ideas. Cultural barriers create problems for people in various forms. Cultural barriers are seen as an important ethical problem because the failure to develop social agreements on the proper use of a particular technology can lead to a decline in social solidarity and the rise of social conflict. The term "cultural barriers" refers to the fact that culture takes time to catch up with technological innovations, leading to social problems.

Material culture in the study of the social sciences is a term developed in the late nineteenth and early twentieth centuries, which refers to the relationship between cultural artifacts and social relationships. It encompasses all physical objects created by human beings and has meaning. It is also a thing that can be discharged, visible, and can be touched like goods, equipment, furniture, machinery dsb.

Non-material culture is opposed to material culture. Non-material culture does not consist of any physical objects or artifacts. Examples of non-material culture are ideas, beliefs, values and norms that shape our society. It consists of the thoughts and behaviors that human beings learn as part of their culture. It covers all abstracts such as politics, economics, language, family, religion, beliefs, values, rituals, knowledge, skills, talents, government, education, etc.

Cultural barriers occur when technological innovation moves faster than cultural adaptation. For example, when a car was first discovered, no legislation governs driving; no speed limit, no guidance as to who should take precedence in the street, no road markings, no stop signs, etc. The result was chaos. Urban roads become dangerous. Legislation were immediately drafted to address this issue. The term cultural barriers is used to describe situations where technological advances or changes in society occur more quickly than changes in rules and cultural values and norms that coincide with it. This can lead to moral and ethical dilemmas against individuals, while new social norms are being developed.

The whole process of this analysis from data selection is conducted through the following steps. First, the data is classified in accordance with the objectives, and then, the classified data is analysed inductively using the theories presented in the methodology as the tools of analysis. It can be continued with the drawing of conclusion. The whole process from data collection, data sorting, data display, to the conclusion is conducted interactively. (Miles and Huberman in Mugijatna in K@TA, 2015: vol 16. No 2).

\section{Findings And Disscussions}

Technological advances in modern society are not always beneficial to everyone, as Ogburn offered the notion that changes are sometimes uneven and material changes occur quickly, so that nonmaterial can not follow effectively.

\section{Virtual Games Became Competitors}

There is a good case study example of this condition, which is the decline and disappearance of toys street-sellers, whose popularity was peaked during 1980s and 1990s. This is conclusively related to technology in the form of sophisticated mobile phone equipped with various games. The children do not 
need to ask their friends to play together, but only with automatic system available in their gadget, they can play with happiness.

Such as the story available in digital media, Vemale.com written by Anisha Saktian Putri, according to toys street-seller named Mang Kodir. In the modern society where the children are more accustomed to gadgets, Mang Kodir struggles to survive. With his cart, he always tried to find justified sustenance by selling toys to schoolchildren and also getting around neighborhoods. Mang Kodir said that he already sells toys, school supplies, and hairpins since 1987 . He only sells those since the beginning, never changed for another product, to secure livelihood for his family, although the children prefer mobile phones nowadays. In a day, Mang Kodir can bring home approximately one hundred thousand rupiahs, which he used to support a family with one wife and four children, all in schooling age. He faced the difficulties during holidays, in which his income is declined due to there is no children buying his merchandises.

In the case of Mang Kodir, we can see the cultural lag or barrier, where traditional games such as board game received little to no response due to the advanced technology, because games can be easily found in mobile phones. This discrepancy caused the declining trend of purchase interest towards traditional games, because it offers no inovation and simpler, more advanced games received more interest.

\section{Regulation, Efficiency and Economic Factors}

Besides the story of Mang Kodir which gave example of street seller who remained active in the wave of globalization and modernisation, there is also the story of a seller in Jatinegara, Jakarta. The seller, who named Kristian, also said that the main factor which causes the difficulty to sell these toys is the regulation stipulating the possession of Indonesian National Standard (SNI/Standar Nasional Indonesia) for the toys, and it also caused difficulties for the sellers' part. The regulation made the seller to discard toys without SNI. This is seen as tough for the children, because the popular items were cheap toys which can be bought by the children, and vast majority of these toys comes from China, because of far lower prices.

Technological advancement in modern era is inevitable, due to its simpler nature. In one hand, every games can be played. Games which traditionally played with boards or balls such as chess pawns, can now be played using mobile phones or other devices. For example, there are the game Let's Get Rich by Line which imitate Monopoly games and Ludo King which replaces Ludo, and the favorite is snakes and ladders game. Besides, through mobile phones or gadgets, people can play without actual opponent, even with distant ones using Internet connection.

With these games in gadgets and mobile phones, it makes playing easier and individual, without worrying about interaction with other players, but this instance can be harmful for one's social life in the future. Children will not understand how to socialise with their environment, because of the games in the gadget. Time becomes worthless, because the games is available anytime, regardless of the time and place. The only thing necessary are gadgets and the player itself.

This phenomenon is certainly interfering the existence of toys street-seller, but the quick changes are not followed by the advancement of ideas from the seller. Kristian and Mang Kodir stated that everyone will get what they deserve, even they tend to let things flow. Kristian also said that SNI caused difficulties. The dilemma of this cultural lag occurred when the material culture, which are gadgets or mobile phones, replace the traditional games they offered, and how material culture possessed by the 
seller is not enough for them to solve their problems and even how those people let things flow in facing their problems, and even more with the obligation of SNI implemented by the government.

\section{Conclusion}

The phenomenon of the decline in the number of toys street-seller today is not without reason. The existence of technological advances due to the wave of globalization and modernisation that resulted in children tending to choose games that can be found in mobile phones and gadgets. In addition to being more effective and efficient in use, they do not have to bother to find playmates and buy the necessary game tools. Everything is provided and set up by a virtual developer application, like friends to play or the tool. This is not only bad for the seller because their merchandise is not salable, but also to the psychological impact and social personality of a child.

It is also a reflection of a problem called cultural barriers, in which there is a gap between material and nonmaterial culture, which makes children prefer mobile games rather than physical tangible games. Through their nonmaterial culture, ideas about technological advances or other means can not be exploited by the seller, and they even tend to resign to the situation. With all the burdens of technological advances and modernization whose speed can not be restrained, they persist in their way, by continuing to sell their merchandises..

\section{References}

Barker, Chris. (2005). Cultural Studies Teori dan Praktek. Yogyakarta: PT Bentang Pustaka.

Basrowi. (2005). Pengantar sosiologi. Bogor: Penerbit Ghalia Indonesia.

Kurniawan, Gani. (2014). Tahun ini Pedagang Mainan Pasar Gembrong Tidak Untung. http://www.tribunnews.com/metropolitan/2014/07/28/tahun-ini-pedagang-mainan-pasar-gembrongtidak-untung (diakses pada 18 Maret 2018, 22.36).

Ogburn, William Fielding. (1923). Social change with respect to culture an original nature. London, New York: Appleton and Comp.

Putri, Anisha Saktian. (2017). Mang Kodir Penjual Mainan Keliling yang Bertahan di Era Gadget. https://www.vemale.com/inspiring/lentera/100994-mang-kodir-penjual-mainan-keliling-yang-bertahandi-era-gadget.html (diakses pada 18 Maret 2018, 22.23).

Ristiana, Yeni. (2012). Skripsi UNY. Pola Interaksi Masyarakat Di Kampung Cyber Rt.36 Rw.09 Taman, Kelurahan Patehan, Kecamatan Kraton, Yogyakarta. Retrieved from http://eprints.uny.ac.id/8877/2/BAB\%201\%20-\%2008413244003.pdf (diakses pada 18 Maret 2018, 22.13).

Soekanto, Soerjono. (2009). Peranan Sosiologi Suatu Pengantar. Jakarta: Rajawali Pers.

Sucinda, Juniardi. (2016). Perubahan Sosial dalam Era Globalisasi dan Reformasi di Indonesia. http://www.kompasiana.com/seringkong/perubahan-sosial-dalam-era-globalisasi-dan-reformasi-diindonesia_57fcb4950f9373de3e8ddaf1 (diakses pada 18 Maret 2018, 20.53). 
Translation: Alimandan (...). Perspektif tentang Perubahan Sosial. (Robert H. Lauer). Jakarta: Rineka Cipta. (Original work published 1993).

Xavier, Dr. M. Sreedevi. (2016). A Kaleidoscopic View of Cultural Lag and Society. Paripex: New Delhi.

\section{Copyrights}

Copyright for this article is retained by the author(s), with first publication rights granted to the journal.

This is an open-access article distributed under the terms and conditions of the Creative Commons Attribution license (http://creativecommons.org/licenses/by/4.0/). 